Ekuitas: Jurnal Pendidikan Ekonomi

Volume 7, Number 2, 2019, pp 75-81

P-ISSN : 2354-6107 E-ISSN : 2549-2292

Open Access: https://ejournal.undiksha.ac.id/index.php/EKU

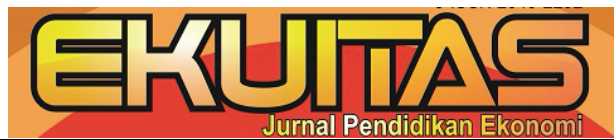

\title{
STUDI KELAYAKAN PENGEMBANGAN PELABUHAN BOLOK DITINJAU DARI ASPEK FINANSIAL
}

\author{
Umbu Joka ${ }^{*}$, dan Rifat Maromon ${ }^{2}$ \\ 1. Prodi Agribisnis Fakultas Pertanian Universitas Timor \\ 2. Prodi Arsitektur Fakultas Sains dan Teknik Universitas Nusa Cendana
}

\section{A R T I C L E I N F O \\ Article history: \\ Received 29 march 2019 \\ Received in revised form \\ 29 april 2019 \\ Accepted 05 December \\ 2019 \\ Available online 11 \\ December 2019 \\ Kata Kunci: \\ Studi Kelayakan, Aspek \\ Finansial, Pelabuhan Bolok \\ Keywords: \\ Feasibilty Study, Financial \\ Aspect, Bolok Harbour}

\begin{abstract}
A B S T R A K
Pengembangan Pelabuhan penyeberangan Bolok di kabupaten Kupang Prov. NTT memerlukan Studi kelayakan finansial, yang hasilnya sangat berpengaruh pada proyek investasi, karena setiap proyek investasi yang akan dilakukan tidak selalu dalam keadaan yang menguntungkan investor. Penelitian ini dilakukan dengan 3 (tiga) tahap yaitu perhitungan cash out (pengeluaran), perhitungan cash in (pendapatan), perhitungan kriteria seleksi. Data primer yang dikumpulkan antara lain data observasi lokasi penelitian yaitu dermaga penyeberangan serta melakukan wawancara berupa tanya jawab, sedangkan untuk data sekunder yaitu BPS Prov. NTT, PT. ASDP Indonesia Ferry Persero cabang Kupang, KSOP, Dinas perhubungan, mengenai standar biaya dermaga, RTRW Provinsi NTT, dan profil Kabupaten Kupang. Dilakukan peramalan tingkat volume penggunaan dermaga dengan metode linier untuk memproyeksikan volume penggunaan dermaga dalam 20 tahun kedepan, kemudian menghitung biaya cash in dan cash out dermaga penyeberangan. Setelah prediksi tingkat volume dermaga penyeberangan, cash in, dan cash out didapat, dilanjutkan dengan analisa cash flow, analisa kelayakan finansial dermaga (NPV, IRR, dan Payback Period). Dari perolehan data dan hasil analisa kelayakan finansial pada pengembangan dermaga penyeberangan untuk 20 tahun kedepan, diperoleh hasil Nilai NPV yang diperoleh
\end{abstract} adalah 47.636.116.308, yang berarti NPV > 0, maka proyek dinyatakan " Layak", Nilai IRR = $23 \%$ $>\mathrm{i}=12 \%$, yang artinya IRR > dari arus pengembalian (i) yang di inginkan (requirred rate of return), maka proyek dikatakan "Layak", Hasil dari perhitungan payback period pada tahun rencana pengembalian investasi yaitu 20 tahun ( $\mathrm{k}=20)$, tahun 2038 modal sudah kembali , maka periode pengembalian investasi dapat dikatakan " Layak".

Kata kunci : Studi Kelayakan, Pelabuhan, Pengembangan

\section{A B S T R A C T}

Development of Bolok ferry port in Kupang East Nusa Tenggara Province requires a financial feasibility study, the results of which are very influential on investment projects, because every investment project that will be carried out is not always in a favorable condition for investors. This research was conducted with 3 (three) stages, namely the calculation of cash out (expenditure), cash in calculation (income), calculation of selection criteria. Primary data collected include observation data of research locations, namely crossing docks and conducting interviews in the form of question and answer, while for secondary data, namely East Nusa Tenggara Central Bureau of Statistics, PT. ASDP Indonesia Ferry Persero Kupang branch, KSOP, Transportation Agency, regarding dock fee standards, NTT Province regional layout plan, and Kupang Regency profile. Forecasting the use of the volume level of the dock with a linear method to project the volume of user use in the next 20 years, then calculate the cost of the crossing dock cash in and cash out. After the prediction of the dock crossing volume level, cash in, and cash out is obtained, followed by cash flow analysis, analysis of the financial feasibility of the dock (NPV, IRR, and Payback Period). in the future,

\footnotetext{
* Corresponding author.

E-mail : umbujoka@unimor.ac.id (Umbu Joka)

$\underline{10.23887 / \text { ekuitas.v7i2.17208 }}$
} 
the results of the NPV value obtained is $47,636,116,308$, which means NPV $>0$, then the project is declared "Eligible", IRR $=23 \%>\mathrm{i}=12 \%$, which means IRR $>$ from the return flow (i) desired (requirred rate of return), the project is said to be "Eligible". The result of the payback period calculation in the investment return plan is 20 years $(\mathrm{k}=20)$, in 2038 the capital has returned, the return period can be said to be "Eligible".

Keywords: feasibility study, port, development

Copyright (C) Ekuitas: Jurnal Pendidikan Ekonomi. All rights reserved.

\section{Pendahuluan}

Provinsi NTT berada di Kawasan Strategis Nasional yaitu kawasan perbatasan antara Australia dan Timor Leste memiliki 550 pulau dengan 3 pulau terbesar dikenal melalui semboyan FLOBAMORATA (Flores, Sumba, Timor, Sabu, Rote, Alor, dan Lembata) yang saling terhubung melalui hubungan ekonomi, sosial dan budaya. Hubungan ini menjadi perhatian pemerintah baik pusat maupun daerah, karena di tahun 2015-2016 provinsi NTT termasuk provinsi urutan ketiga termiskin di Indonesia setelah Papua dan Papua Barat.

Data BPS NTT Tahun 2018 menunjukkan jumlah penduduk miskin di NTT mencapai 21,35 persen atau 1.142 .170 orang dari sekitar 5,2 juta penduduk. Penduduk yang memiliki penghasilan per bulan Rp.1.700.000 tidak termasuk kategori miskin. Untuk mendongkrak perekonomian sesuai kebijakan Nasional Tol Laut maka Penyeberangan Feri yang dikelola oleh ASDP menjadi pilihan utama masyarakat karena harga tiket terjangkau dan penumpang dapat membawa barang dalam jumlah besar seperti ternak, komoditi pertanian, barang dagangan dan bahan bangunan serta untuk mendukung pariwisata antar pulau di NTT.

ASDP di Provinsi NTT memiliki tiga pelabuhan yaitu pelabuhan Bolok Kupang, Pelabuhan Pantai Baru Rote dan Pelabuhan Waibalun Larantuka. Melayani 25 rute pelayaran di NTT menghubungkan antar Pulau dari 22 Kabupaten. Dari ketiga pelabuhan ini, pelabuhan Bolok sebagai pelabuhan terbesar berada sekitar $10 \mathrm{~km}$ dari ibu kota provinsi dan masuk dalam kawasan industri dan per gudangan Bolok dan Tenau.

Selama tahun 2012-2017 terjadi fluktuasi jumlah penumpang, pada tahun 2012 sebanyak 323.830; Tahun 2013 terjadi penurunan 301.293, Tahun 2014 mengalami kenaikan 327.386, Tahun 2015 menurun 320.909; Tahun 2016 mengalami kenaikan sebesar 344.266 dan di tahun 2017 sebesar 351.899. Perkembangan ini didukung oleh bertambahnya 2 kapal feri dengan bobot 1600Gt.

Peningkatan jumlah pendapatan dan jumlah penumpang ternyata tidak sejalan terhadap pemanfaatan terminal penumpang dan aneka usaha jasa di sekitar kawasan pelabuhan Bolok mengalami penurunan pendapatan sebesar $12 \%$ dalam tiga tahun terakhir, padahal sebagai fasilitas pokok dari pelabuhan Feri Bolok yang memiliki fungsi menampung dan menghubungkan penumpang antar moda transportasi, Terminal Penumpang sewajarnya mengalami peningkatan pendapatan. Penurunan pendapatan dipengaruhi oleh berbagai faktor yang berdasarkan observasi, wawancara dan analisa maka penelitian ini bertujuan menganalisis kelayakan Finansial kawasan terminal Bolok

\section{Metode}

Metode yang digunakan dalam penelitian ini adalah metode yang didasarkan pada sifat mengoptimalkan tingkat pelayanan atau kinerja transportasi bagi penduduk sehingga pergerakan barang dan orang dalam kota atau kecamatan atau antar pulau akan relatif lebih efektif dan efisien. Berkaitan dengan pekerjaan studi ini, maka peneliti dalam analisis data merencanakan menerapkan analisis terhadap isi dokumen, analisis regresi linier dan analisis hirarkhi proses. Gabungan dari analisis data ini menggunakan teknik deskriptif kualitatif dan didukung dengan teknik kuantitatif melalui pengolahan data kualitatif dan kuantitatif. Analisis data gabungan ini tepat untuk menjawab rumusan masalah tentang bagaimana mengembangkan kawasan perindustrian Bolok Kabupaten Kupang, Provinsi Nusa Tenggara Timur. Lokasi penelitian ini yaitu di kawasan perindustrian Bolok Kecamatan Kupang Barat Kabupaten Kupang, Provinsi Nusa Tenggara Timur. Jenis dan sumber data yang digunakan dalam penelitian ini yaitu (a) data primer: wawancara secara lisan, observasi lapangan, (b) data sekunder : pedoman/peraturan mengenai data administrasi dan kondisi fisik wilayah, Rencana Tata Ruang Wilayah Nasional dan Daerah, data sosial budaya, data potensi ekonomi wilayah, dan standar biaya untuk pembangunan dermaga penyeberangan.

Metode pengumpulan data yang digunakan dalam penelitian ini adalah Wawancara. Dimana wawancara adalah proses untuk memperoleh data untuk penelitian dengan cara tanya jawab, sambil bertatap muka antara penanya dan narasumber. Teknik wawancara pada penelitian ini adalah teknik 
wawancara terstruktur kepada pihak-pihak yang terkait, yaitu pihak ASDP, Pengguna jasa pelabuhan (Penumpang dan penyewa tenant) KSOP, Dinas Perhubungan, dan Dinas Pariwisata. Dan komponen yang diperlukan dalam penyusunan Analisis Kelayakan Finansial yang dipakai dalam Kajian Pengembangan Pelabuhan Bolok meliputi: (1) Asumsi Dasar Perhitungan, sebagai titik tolak dari analisis finansial, diasumsikan bahwa studi-studi yang telah dilakukan sebelumnya menghasilkan parameter dasar sebagai landasan membuat perkiraan biaya sebagai batasan lingkup proyek. Asumsi dasar ini biasanya mencakup umur proyek, suku bunga pinjaman yang berlaku, kapasitas produksi, jumlah hari kerja produksi, harga yang berlaku, modal yang digunakan, biaya pemeliharaan dan penyusutan mesin/peralatan produksi, dan lain sebagainya, (2) Perhitungan biaya pemeliharaan adalah biaya yang dikeluarkan untuk perawatan kapal dan Bangunan serta Instrument yang ada didalamnya. Komponen adalah biaya perawatan preventif, biaya perawatan korektif, dan biaya Overhaul, (3) Perhitungan biaya penyusutan, biaya penyusutan adalah biaya yang dikeluarkan akibat penurunan nilai kapal atau bangunan. Metode yang digunakan adalah metode depresiasi garis lurus (Straight Line) yaitu Metode yang berdasar pada asumsi bahwa nilai aset berkurang secara proporsional terhadap waktu atau umur dari aset tersebut. Komponen biaya penyusutan Kapal/ Bangunan adalah nilai awal aset, nilai sisa aset, dan masa pakai (umur). Dengan perhitungan;

$$
D=\frac{P-S}{N}
$$

Dimana :

$\begin{array}{ll}\mathrm{D} & \text { : Biaya penyusutan } \\ \mathrm{P} & \text { : Nilai awal asset } \\ \mathrm{S} & \text { : Nilai sisa asset } \\ \mathrm{N} & \text { : masa pakai aset }\end{array}$

Selanjutnya (4) perhitungan kapasitas produksi, kapasitas produksi adalah kemampuan perusahaan untuk menghasilkan sejumlah produk per satuan waktu dalam kaitanya dengan besarnya kapasitas produksi baik di perusahaan barang ataupun jasa. Besarnya kapasitas produksi merupakan parameter penting yang dapat dipakai sebagai masukan dalam perhitungan aspek kelayakan finansial dalam analisis kelayakan suatu usaha. Dalam menghitung kapasitas produksi terlebih dahulu dilakukan analisi biaya yang terdiri dari: a) biaya investasi adalah biaya yang dikeluarkan untuk mendapatkan aktiva tetap yang akan digunakan perusahaan untuk menjalankan aktivitas usahannya. Biaya investasi dalam hal ini biaya yang nantinya akan di keluarkan perusahaan baik untuk bangunan, sewa tanah, pembelian mesin/ peralatan produksi dan lain-lain, b) biaya tetap adalah biaya produksi yang jumlah totalnya tetap meskipun volume produksi berubah. Komponen biaya tetap meliputi biaya pemeliharaan dan biaya penyusutan. Biaya variabel adalah biaya produksi yang jumlah totalnya berubah secara proporsional terhadap perubahan volume produksi. Komponen biaya variabel meliputi biaya bahan baku, biaya bahan pembantu, biaya bahan pengemas, biaya utilitas, dan upah tenaga kerja. Estimasi biaya dicari menggunakan metode trend linier dan beberapa biaya yang telah ditetapkan perusahaan. Hasil perhitungan menyimpulkan bahwa estimasi biaya cenderung mengalami peningkatan dari Tahun ke Tahun, c) perkiraan laba rugi adalah cara untuk melihat profitabilitas suatu usaha, yang disusun secara sitematis. Prakiraan laba rugi digunakan untuk melihat besaran keuntungan atau kerugian yang dialami oleh perusahaan dalam kurun waktu tertentu untuk memperoleh cash flow perusahaan, dan d) kelayakan investasi, sebuah proyek dapat dikatakan layak atau tidak secara finansial dapat diketahui dari kriteria investasi. Berdasarkan nilai uang, kriteria investasi antara lain Net Present Value (NPV), Internal Rate of Return (IRR) dan Benefit of Cost, sedangkan berdasarkan nilai waktu antara lain Payback Periode (PP) dan Return On Invesment (ROI). Kriteria investasi tersebut dapat dijelaskan sebagai berikut: 1) Net Present Value (NPV), dalam metode ini digunakan faktor diskoton. Semua pengeluaran dan penerimaan dimana saat pengeluaran dan penerimaannya adalah dalam waktu yang tidak bersamaan. Urut-urutan perhitungan dalam metode ini yaitu: (a) menghitung cash flow yang diharapkan dari investasi yang akan dilaksanakan, (b) mencari nilai sekarang (Present Value) dari cash flow dengan mengalikan tingkat diskonto tertentu yang ditetapkan, (c) kemudian jumlah nilai sekarang atau Present Value dari cash flow selama umur investasi dikurangi dengan nilai investasi awal akan menghasilkan Net Present Value (NPV). Net Present Value dari investasi itu dapat diperoleh dengan menggunakan formulasi sebagai berikut:

Keterangan :

$$
\begin{gathered}
\mathrm{NVP}=\frac{P 1}{(1+i)^{1}}+\frac{P 2}{(1+i)^{2}}+\frac{P 3}{(1+i)^{3}} \ldots+\frac{P n}{(1+i)^{n}} \\
\mathrm{NPV}=\sum_{1}^{n} \frac{\mathrm{Pt}}{(1+i)^{t}}-\mathrm{IO}
\end{gathered}
$$


Pt = Net Cash Flow pada tahun ke-t

$\mathrm{i} \quad=$ Tingkat diskonto

$\mathrm{n} \quad$ = Lama waktu atau perode perlangsungan investasi

IO = Pengeluaran mula-mula atau nilai investasi awal

Selanjutnya 2) Internal Rate of Return (IRR), internal rate of return merupakan metode penilaian kelayakan proyek dengan menggunakan perluasan metode nilai sekarang. pada posisi NPV $=0$ akan diperoleh tingkat persentase tertentu. proyek dinilai layak jika IRR lebih besar dari persentase biaya modal atau sesuai dengan persentase keuntungan yang ditetapkan oleh investor, dan sebaliknya, proyek dinilai tidak layak jika IRR lebih kecil dari biaya modal atau lebih rendah dari keinginan investor, dan 3) Payback Periode (PP), metode analisis payback period bertujuan untuk mengetahui seberapa lama (periode) investasi akan dapat dikembalikan saat terjadinya kondisi break even-point (jumlah arus kas masuk sama dengan jumlah arus kas keluar). Analisis payback period dihitung dengan cara menghitung waktu yang diperlukan pada saat total arus kas masuk sama dengan total arus kas keluar. Dari hasil analisis payback period ini nantinya alternatif yang akan dipilih adalah alternatif dengan periode pengembalian lebih singkat. Penggunaan analisis ini hanya disarankan untuk mendapatkan informasi tambahan guna mengukur seberapa cepat pengembalian modal yang diinvestasikan.

$$
\text { Payback Period }=n+\frac{a-b}{c-b} \times 1 \text { tahun }
$$

$\mathrm{n}=$ Tahun terakhir dimana jumlah arus kas masih belum bisa menutup investasi mula-mula

$\mathrm{a}=$ Jumlah investasi mula-mula

$\mathrm{b}=$ Jumlah kumulatif arus kas pada tahun ke $-\mathrm{n}$

$\mathrm{c}=$ Jumlah kumulatif arus kas pada tahun ke $\mathrm{n}+1$

\section{Hasil dan pembahasan}

Gambaran Umum, Keputusan MENHUB No. KP901 T ahun 2016 T entang Rencana Induk Pelabuhan Nasional (RIPN) mensyaratkan penetapan RIPN dengan memperhatikan Rencana Tata Ruang Wilayah (RTRW). RTRW Nasional mencanangkan Provinsi NTT menjadi : (1) Provinsi NTT termasuk kawasan strategis Nasional (KSN) berbtasan dengan Negara Australia dan Republic Democratic Timor Leste (RDTL); (2) Provinsi NTT termasuk Kawasan Strategis Pariwisata Nasional (KSPN); (3) Provinsi Kawasan Peruntukan Peternakan Nasional.

RTRW Provinsi NTT yang bertujuan untuk mewujudkan Provinsi Nusa Tenggara Timur sebagai Provinsi Kepulauan dan maritim yang berbasis pada pengembangan potensi sumber daya alam dan budaya local yang terpadu dan berkelanjutan, bertumpu pada masyarakat berkualitas , adil, dan sejahtera, dengan tetap memperhatikan aspek mitigasi bencana. RTRW Provinsi NTT merencanakan Provinsi nTT menjadi : (1) Kawasan tenun Ikat, souvenir, mebel, komoditi Kopi, Kemiri, Kenari, Pinang, Jambu Mete, Ikan dan Daging,; (2) Kawasan Ternak Besar; (3) Kawasan Pariwisata; (4) kawsan industri besar Tenau dan Bolok.

Peraturan Menteri Perhubungan no. 51 tahun 2015 tentang standar Prelayanan Minimum Penumpang Angkutan Penyeberangan, menjabarkan bahwa Standar Pelayanan Minimum Penumpang Angkutan Penyeberangan Meliputi 6 dimensi, yaitu : (1) Keselamatan, informasi dan fasilitas keselamtan serta kesehatan; (2) Keamanan, meliputi Fasilitas dan petugas keamanan, informasi dangguan keamanan, dan lampu penerangan; (3) Kehandalan, tersedianya loket penjualan tiket; (4) Kenyamanan Ruang tunggu toilet, mushola, penerangan, fasilitas pengatur suhu; (5) Keterjangkauan, tersedianya informasi pelayanan, gangguan pelayanan kapal, angkutan lanjutan, fasilitas layanan penumpang, kemudahan naik/turun penumpang, tempat parkir, pelayanan bagasi penumpang; (6) Kesetaraan, fasilitas bagi penumpang difabel, dan ruang ibu menyusui.

Proyeksi kinerja keuangan, mengunakan asumsi pendekatan dasar perhitungan, Proyeksi kapasitas produksi, analisis biaya, kelayakan investasi, dari pelabuhan Bolok sesudah pengembangan dari PT. ASDP Indonesia Ferry (Persero) Cabang Kupang. Kemudian dengan mengunakan analisis biaya investasi merupakan biaya awal yang dikeluarkan untuk melakukan pengembangan. Selanjutnya komponen investasi gedung terminal bolok. Jumlah anggaran investasi yang berumber alokasi anggaran investasi Cabang Kupang akan dikeluarkan sebesar Rp 22.631.400.000,-. Untuk investasi pengembangan pembangunan gedung terminal pelabuhan Bolokselengkapnya akan diuraikan pada Tabel 1. 
Tabel 1. Komponen Investasi Gedung Terminal Bolok

\begin{tabular}{|l|l|c|}
\hline NO. & Jenis Investasi & Biaya \\
\hline 1. & Investasi awal & Rp. 20.574 .000 .00 \\
\hline 2. & PPN $10 \%$ & Rp. 2.057 .400 .00 \\
\hline 3. & Total & Rp. 22.631 .400 .00 \\
\hline
\end{tabular}

Prakiraan laba rugi adalah cara untuk melihat profitabilitas suatu Usaha, yang disusun secara sitematis. Prakiraan laba rugi digunakan untuk melihat besaran keuntungan atau kerugian yang dialami oleh perusahaan dalam kurun waktu tertentu untuk memperoleh cash flow perusahaan dengan metode langsung.

Berdasarkan perhitungan Ability to Pay (ATP) dan Willingness to Pay (WTP) diperoleh bahwa ratarata pengguna jasa baik itu penumpang dan pengantar yang menggunakan jasa penyeberangan Kapal Ferry di Pelabuhan Bolok bersedia mengeluarkan dana lebih demi memperoleh fasilitas yang nyaman dan layak (ATP>WTP) sesuai dengan Peraturan Menteri Perhubungan Republik Indonesia Nomor PM 104 TAHUN 2017 Tentang Penyelenggaraan Angkutan Penyeberangan sehingga kenaikan pass masuk ke gedung terminal untuk mengakses berbagai fasilitas berupa ruang tunggu, ruang menyusui, dan tenant layak dinaikkan sebesar $25 \%$ dari Rp. 5000,- menjadi Rp.7.500,- pada saat gedung terminal baru mulai beroperasi.

Dalam menghitung proyeksi keuangan digunakan asumsi bahwa pengerjaan Pengembangan dilakukan secara bertahap, yakni tahap I Gedung Terminal yang baru mulai beroperasi semester ke-2 tahun 2019 atau sekitar bulan Juli, Tahap II Area Parkir yang diperkirakan selesai pertengan 2020, dan Tahap III Gangway pertengahan 2021. Setelah selesainya pembanguanan gedung terminal penumpang mulai dapat dilakukan strelisasi terhadap penumpang maupun pengantar yang menggunakan area gedung Terminal. Dengan mengunakan cash flowdapat menjadi dasar perhitungan analisis kelayakan finansial dan mengetahui cash flow Terminal (sisa nilai penyusutan) yang mengambarkan estimasi sisa nilai buku tersebut sudah negatif berarti sebelum sampai umur ekonomis 20 Tahun berakhir investasi sudah kembali.Selengkapnya dapat dilihat pada Tabel 2. Prakiraan rugi laba dan cash flow. 
Tabel 2. Prakiraan Laba Rugi dan Cash Flow

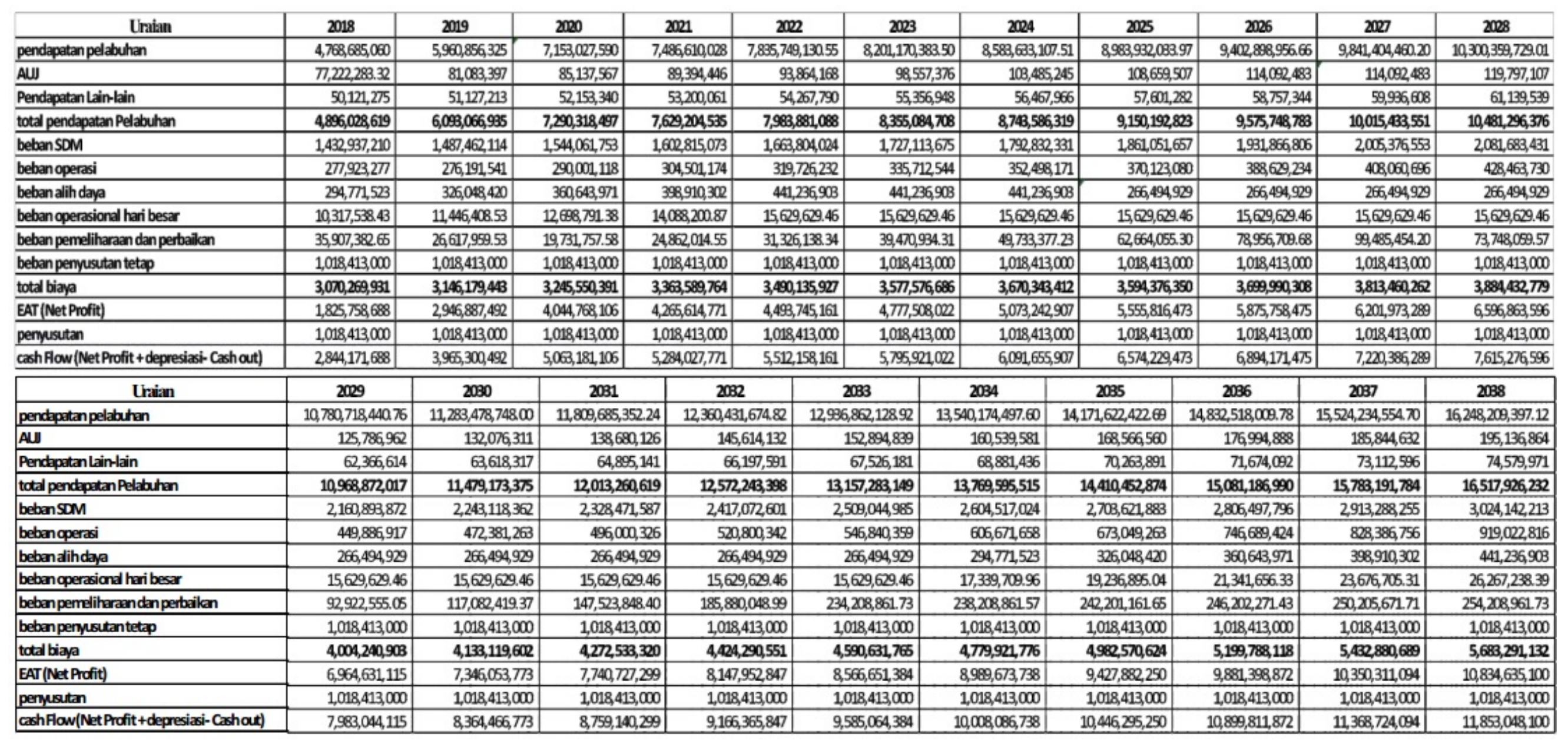


Dan yang terakhir yakni analisis kelayakan finansial. Hasil perhitungan analisis kelayakan financial pengembangan pelabuhan Bolok tanpa pendapatan penyeberangan maka diperoleh nilai untuk kriteria kelayakan usaha dan analisis investasinya.

Tabel 3. Kelayakan Investasi

\begin{tabular}{|l|l|l|l|}
\hline \multicolumn{2}{|c|}{ Analisis Kelayakan Hasil } & \multicolumn{1}{c|}{ Rekomendasi } \\
\hline \multicolumn{5}{|c|}{ Analisis Usaha } \\
\hline 1. & Payback Period (PP) & 4 tahun 9 bulan & Layak \\
\hline \multicolumn{5}{|c|}{ Analisis Investasi } \\
\hline 1. & NPV & Rp. 47.636.116.308,- & Layak \\
\hline 2. & IRR & $23 \%$ & Layak \\
\hline
\end{tabular}

Dari perolehan data dan hasil analisa kelayakan finansial pada pengembangan dermaga penyeberangan untuk 20 tahun kedepan, diperoleh hasil Nilai NPV yang diperoleh adalah 47.636.116.308, yang berarti NPV > 0, maka proyek dinyatakan "Layak", Nilai IRR $=23 \%>\mathrm{i}=12$ $\%$, yang artinya IRR > dari arus pengembalian (i) yang di inginkan (requirred rate of return), maka proyek dikatakan " Layak", Hasil dari perhitungan payback period pada tahun rencana pengembalian investasi yaitu 20 tahun $(\mathrm{k}=20)$, tahun 2038 modal sudah kembali , maka periode pengembalian investasi dapat dikatakan " Layak".

\section{Kesimpulan}

Nilai NPV 47.636.116.308, yang berarti NPV > 0, maka proyek dinyatakan "Layak", Nilai IRR $=23 \%>\mathrm{i}=12 \%$, yang artinya IRR > dari arus pengembalian (i) yang di inginkan (requirred rate of return), maka proyek dikatakan " Layak", Hasil dari perhitungan payback period pada tahun rencana pengembalian investasi yaitu 20 tahun ( $\mathrm{k}=20)$, tahun 2038 modal sudah kembali , maka periode pengembalian investasi dapat dikatakan "Layak". Hasil dari perhitungan payback period pada tahun ke $20(\mathrm{k}=10)$ yaitu tahun 2038, tahun yang menjadi rencana pengembalian investasi modal telah kembali,maka periode pengembalian investasi belum memenuhi syarat dan dapat dikatakan "Layak".

Jadi, secara keseluruhan proyek pembangunan pengembangan dermaga penyeberangan Bolok di Kabupaten Kupang Provinsi Nusa Tenggara Timur "Layak" secara finansial. Namun pembangunan dermaga Bolok bukan untuk tujuan profit oriented, melainkan pemerintah mengharapkan bahwa dengan adanya dermaga ini dapat memacu pertumbuhan ekonomi daerah Kupang dan kepulauan yang ada di provinsi NTT lainnya.

\section{Daftar Rujukan}

Badan Pusat Statistik Kabupaten Kupang .2017. Kecamatan Kupang Barat dalam Angka 2017.

Badan Pusat Statistik Kabupaten Kupang.2017. Kabupaten Kupang dalam Angka 2017.

Dinas Perhubungan Provinsi NTT. Peraturan Menteri Perhubungan Republik Indonesia Nomor 75 Tahun 2013 Tentang Standar Biaya Tahun 2014 di Lingkungan Kementerian Perhubungan. Dinas Perhubungan Provinsi NTT. 2017

Undang-undang Nomor 17 Tahun 2008 tentang Pelayaran

Peraturan Gubernur NTT no. 1 Tahun 2018 Tentang Tarif Angkutan Penyeberangan Lintas Antar Kota/Kabupaten Dalam Provinsi Nusa Tenggara Timur

Peraturan Menteri Perhubungan no. 104 tahun 2017 tentang penyelenggaraan angkutan penyeberangan Peraturan Pemerintah No. 38 tahun 2007 Tentang Pembagian Urusan Pemerintah antara Pemerintah Daerah Provinsi dan Pemerintah Kabupaten/Kota.

Peraturan Pemerintah Nomor 26 Tahun 2008 tentang Rencana Tata Ruang Wilayah Nasional

Soeharto, Iman. 1995 “Manajemen Proyek dari Konseptual Sampai Operasional” Penerbit Erlangga: Jakarta.

Triton, P.B. 2005 "Manajemen Investasi Proyek" Penerbit Tugu Publiser: Yogyakarta

Wulfram I. Ervianto, 2005, Manajemen Proyek Konstruksi (Edisi Revisi), Andi Offset, Yogyakarta. 